\title{
Studies on some harmful and beneficial bird species in newly reclaimed areas in Sohag Governorate
}

\section{M. Omar}

Zoology and Nematology Department, Faculty of Agriculture, Al-Azhar University, Assiut Branch, Egypt

*Corresponding author E-mail: Mahmoud.omar75@azhar.edu.eg (M. Omar).

\begin{abstract}
In African countries, birds damage to cereal crops represents economic losses. Serial field trials had been conducted to study some ecological aspects associated with harmful and beneficial bird species at newly reclaimed areas in Sohag Governorate, Upper Egypt. Regarding the harmful bird species, it is clear that the house sparrow, Passer domesticus niloticus was the most prevalent species in newly reclaimed areas, throughout the different year seasons. Hooded crow, Corvus corone sardonius ranked the second followed by palm dove, Streptopelia senegalensis egyptica and rock dove, Columba livia schimpari. On the other hand, crested lark, Galerida cristata and little green beeeater, Merops orintalis clepatra were found in a few numbers during all seasons of the year. For the beneficial bird species, the results revealed that 9 beneficial and resident bird species Black-winged kite, Elanus coeruleus; fantailed warbler, Cisticola juncidis; hoopoe, Upupa epops epops; kestrl, Falco tinnunculus; little owl, Athene noctua glaux; swallow, Hirundo rustica savignii; spur winged plover, Hoplopterus spinosus; yellow wagtail, Motacilla flava and cattle egret, Bubulcus ibis ibis. White wagtail, Motacilla alba alba and chiffchaff, Phylloscopus collybita were found abundantly only in winter and spring seasons. With respect to the loss caused by harmful birds, the results revealed that the average of birds damage to wheat and sorghum varied according to the type of habitats. The highest birds damage occurred in crops of nearby trees, while the lowest damage was in those nearby field crops. Also, the most birds damage was recorded in the first 10 meters then, it decreased gradually towards the middle of the field. In conclusion, house sparrow, caused the most serious damage at ripening stage of considered crops. The highest damage was occurred in most cases during the ripening stages of sorghum than that of wheat crop.
\end{abstract}

Keywords: Survey; Population; Newly reclaimed areas; Birds damage; Wheat; Sorghum.

\section{INRODUCTION}

The combination of both the geographical position and great diversity of habitats in Egypt makes it of particular importance to many types of bird life. On the 515 bird species occurring in Egypt, about 186 bird species, 12 are extinct and 17 are endemic. The rest of bird species and sub species 300 bird species are migratory (Tharwat, 1997). Recently in Egypt, the house sparrow, Passer domesticus niloticus L. hooded crow, Corvus corone sardonius L. and palm dove, Streptopelia senegalensis egyptica L. were the resident birds in Egypt during all seasons of the year (Metwally et al. (2009) and Mosallm (2017). An important part of the study of birds causing damage to agricultural crops is the description and delimitation of their habitat, and their way of life within this habitat, in other words, their natural history. In African countries, birds damage to cereal crops represents economic losses that reached to 5 - $10 \%$ of the production (Bruggers and Rulle 1981). In Egypt, Omar and EL-Danasory (2014) and Hassan (2018) recorded that the wild bird species that can cause serious damage to many field crops during the ripening stages under the different conditions of some governorates. The above reports indicated the seriousness of the economic important of bird pest's problem. The previous trials figured that the both resident and migratory birds are of great importance in our lives, which made a lot of researchers and scholars to the interest in the study of ornithology and conduct field studies to determine the characteristics and behavior of the birds. The aim of the present study is to survey the population dynamics of some wild bird species and to assess the birds damage on wheat and sorghum crops.

\section{MATRIALS AND METHODS}

\section{Survey of harmful and beneficial bird species}

The harmful and beneficial bird species were surveyed in newly reclaimed areas in Akhmim and Tahta districts in Sohag Governorate during two successive years (2015/2016 and 2015/2016). In these trails, area size is two feddans inside the chosen cultivated habitat. The number of the different bird species was counted in each habitat, by using the method of Redinger and Libay (1979) as a plot equivalent to two feddans from the determined cultivated area in each habitat. The identification and counts of bird species were achieved by using field glass (binoculars) from a rising position, which gave clear sighted vision of the plots. This work has been accomplished twice daily, the first at sunrise and second at sun-set during one hour for four days monthly. Bird classification were 
carried out by Sibley and Monoroe (1990) under review by the checklist committee of the American Ornithologists Union (A. O. U.) were followed in bird classification.

\section{Assessment of birds damage on wheat and sorghum crops}

For wheat and sorghum crops the damage assessment was conducted in newly reclaimed areas in Akhmim and Tahta districts at Sohag Governorate during 2015/2016 season, with three locations, nearby (buildings, field crops and trees) and the effect of the distance was studied from the beginning of the field experiment. The different distances from the border were $(10,20,30,40$ and $50 \mathrm{~m})$ for wheat and sorghum crops. 12 feddans cultivated with wheat and sorghum crops were randomly chosen in the above mentioned location. Sampling was done according to the methods adopted by Poche et al. (1982). A wooden square meter frame was used for twenty-five times randomly at different portions of selected fields. The samples were taken weekly starting from the appearance of ears till the harvest. The percentage damage of each ear was scored in different categories according to De-Haven (1975) as the following

Birds damage $(\%)=\frac{\begin{array}{c}\text { No. of } \\ \text { damaged ears }\end{array}}{\begin{array}{c}\text { Total } \\ \text { investigated } \\ \text { ears }\end{array}} \times 100$

\section{Statistical analysis}

Data obtained were statistically analyzed using a randomized complete block design. Means were compared according to Duncan's Multiple Range test, at 0.05 level of probability.

\section{RESULTS AND DISCUSSION}

\section{Survey of harmful and beneficial bird species}

A survey of harmful and beneficial wild bird species was carried in newly reclaimed areas with three different habitats nearby (buildings, field crops and trees) in Akhmim and Tahta districts of Sohag Governorate during two successive years, from January, 2015 to December, 2017, where birds were surveyed and counted. Data of the relative abundance of different bird species are tabulated in Tables (1 and 2).

\section{Harmful wild bird species}

Data in Table (1) showed the survey of 6 harmful bird species: crested lark, Galerida cristata and little green bee-eater, Merops orintalis clepatra. These species were found in a few numbers during all seasons of the year of the study. hooded crow, Corvus corone sardonius; palm dove, Streptopelia senegalensis egyptica and rock dove, Columba livia schimpari there were found in moderate numbers. But the house sparrow, Passer domesticus niloticus was found in high numbers during spring and summer seasons, followed by winter and autumn at newly reclaimed areas in Akhmim and Tahta districts. The highest numbers of house sparrow were recorded during spring and summer seasons, and this may be related to the appearance of wheat ears and broad bean horns till the harvest during spring season. On the other hand, the second peak was recorded during summer season; this may be due to the appearance of the head sorghum and sunflower crops in the studied areas. Metwally et al., (2009) recorded twenty-seven bird species belonging to 9 orders and 21 families from different habitat in old land at Assiut governorate. Mosallm (2017) found that 7 harmful birds' species in Assiut Governorate. The harmful bird species were: house sparrow, hooded crow, palm dove, crested lark, rock dove, little green bee-eater and pied kingfishe. Hassan (2018) revealed that the house sparrow, Passer domesticus niloticus bird species were found with higher abundance all over the year than the other bird.

\section{Beneficial wild bird species}

Data in Table (2) showed the presence of 11 beneficial bird species in the studied area. 9 beneficial and resident bird species were found to be: black-winged kite, Elanus coeruleus; fantailed warbler, Cisticola juncidis; hoopoe, Upupa epops epops; kestrl, Falco tinnunculus; little owl, Athene noctua glaux; swallow, Hirundo rustica savignii; spur winged plover, Hoplopterus spinosus. These birds were found in a few numbers during winter, spring, summer and autumn seasons in Akhmim and Tahta districts. Also, Yellow wagtail, Motacilla flava was found in a few numbers during winter and spring seasons. But, it was absent during summer and autumn seasons. cattle egret, Bubulcus ibis ibis was found in moderate numbers. Two migratory bird species were white wagtail (Motacilla alba alba), that were found in moderate numbers during winter and spring seasons and chiffchaff (Phylloscopus collybita) which was found in a few numbers during winter and spring seasons. White wagtail and chiffchaff birds were absent during summer and autumn seasons in the studied areas of Akhmim and Tahta districts. These results agree with Mosallm (2017) who observed that there are 11 
beneficial wild bird species: cattle egret, common bulbul, fantailed warbler, hoopoe, swallow, sand martin, rufos-taild robin, spur winged plover, black winged kite, kestrel and little owl.

\section{Classification of wild bird species:}

The obtained results revealed that the bird species collected from this area could be classified according to the full description of Thomson (1964) as follows:

\section{Kingdom: Animalia \\ Phylum: Chordata \\ Subphylum: Vertebrata \\ Class: Aves \\ Subclass: Newornithes}

From data showed in the Table (3), the bird species in the present study were 17 species of 15 families and 7 orders. (1) Order: Accipitres showed that two bird species represent families Acciptridae and Falconidae. The bird species were black-winged kite, Elanus coeruleus and Kestrl, Falco tinnunculus. (2) Order: Ciconiformes, only one species, Cattle egret, Bubulcus ibis ibis was belonging to family Ardeidae. (3) Order: Coracuformes, this was represented by the hoopoe, Upupa epops epops; little green bee-eater, Merops orintalis clepatra These bird species were belonging the families (Upupidae and Miropidae). (4) Order: Columbiformes showed that two bird species were represented by family, Columbidae. The bird species were palm dove, Streptopelia senegalensis egyptica and rock dove, Columba livia schimpari. (5) Order: Charadrufomes, one species was belonging to family Charadrudae. This bird species was spur winged plover, Hoplopterus spinosus. (6) Order: Passeriformes, presented by 8 species belonging to 7 families. The families and species were, chiffchaff, Phylloscopus collybita; fantailed warbler, Cisticola juncidis; swallow, Hirundo rustica savignii; White wagtail, Motacilla alba alba; yellow wagtail, Motacilla flava; crested lark, Galerida cristata; hooded crow, Corvus corone sardonius and house sparrow, Passer domesticus niloticus. These bird species were belonging the families (Sylviidae, Muscicapidae, Hirundidae, Motacillidae, Alaudidae, Corvidae and Passeridae), respectively. (7) Order: Strigiformes, consist of one bird species representing by family, Strigidae. The bird species was little owl, Athene noctua glaux. These results are agree with those obtained by Abbasy et al. (2011) reported that twenty families contain 6 genera and twentyseven species were recorded during study of the wild birds at Ismailia Governorate. These species were recorded as resident bird species during study period from April 2007 to March 2009 and arranged according to economic important as follow, 15 species were recorded as harmful birds and 12 species were recorded as beneficial birds belonging to 20 families and 9 orders. 6 species were recorded as migratory birds during this study. Hassan (2018) found that the wild bird survey of species in old areas at Akhmim and Tahta districts of Sohag Governorate were 21 species of to 20 genera, 18 families and 8 orders (Strigiformes, Accipitres, Ciconiformes, Passeriformes, Coracuformes, Gruiformes, Columbiformes and Charadrufomes).

\section{Assessment of birds damage on wheat and sorghum}

The work herein was carried out to estimate the damage caused by birds in wheat and sorghum. The damage caused by birds on wheat and sorghum fields nearby (buildings, field crops and trees). And the different distances from the border $(10,20,30,40$ and $50 \mathrm{~m}$.) in newly reclaimed areas at Akhmim and Tahat districts in Sohag Governorate during 2015 / 2016 season.

\section{In Akhmim district}

Data in Table (4) show the average percentages of pest birds damage to ripening stage for wheat and sorghum under the conditions of different habitat of newly reclaimed areas at Akhmim district in Sohag Governorate during 2015/2017 season. The obtained results revealed that the bird damage varied from crop to another and from location to another depending on the prevailing agroecosystem and weather conditions. It was found that, the highest damage occurred to field crops, nearby trees followed by those nearby buildings and field crops. Generally, the lowest damage was observed, respectively, in the centeral area of each respective field crop tested. The average percentage of total damage was $(14.20,6.60$ and $3.00 \%)$ and 22.00, 17.20 and $2.80 \%$ ), for wheat and sorghum, respectively. It has been observed that the highest damage was recorded in the first 10 meters then decreased gradually towards the middle of the field the statistical analysis of data shows that, there are significant differences between the distances. The average percentage of distances was (17.00, $12.67,6.67,2.33$ and $1.00 \%)$ and $(30.67,19.33$, $11.00,6.33$ and $2.67 \%$ ) for wheat and sorghum crops, respectively. 


\section{In Tahta district}

Data in Table (5) show the damage caused by house sparrow birds to wheat and sorghum fields nearby (buildings, field crops and trees) and the different distances from the field border in Tahta district during 2015/2016 season. The highest damage caused by sparrow birds was recorded in fields nearby trees (8.80 and 19.20 $\%)$ for wheat and sorghum crops, followed by fields nearby buildings (5.40 and $16.00 \%$ ). But the lowest birds damage was in the wheat and sorghum field nearby field crops (1.60 and $5.20 \%$ ). It has been observed that the highest damage was recorded in the first 10 meters then it decreased gradually towards the middle of the field. The statistical analysis of data shows that, there are significant differences between the distances, for wheat and sorghum crops.. Omar and EL-Danasory (2014) mentioned that, the highest damage of wheat occurred at the nearby cultivations of buildings and animal husbandry (25.87 and $19.20 \%$ ). On the other hand, the lowest damage was observed in the nearby cultivations of orchards (9.33\%).

\section{CONCLUSION}

Reviewing the above mentioned results, it could be concluded that bird damage varied according to type of crop, distances from the field border, areas and environmental conditions of the studied location. In this study, house sparrow, Passer domesticus niloticus caused the most serious damage at ripening stage of considered crops. The highest damage was occurred in most cases during the ripening stages of sorghum than that of wheat crop. This variation may be due mainly to the variation in morphology and phonology characteristics of plant and seeds. Also, it has been observed that the highest damage was recorded in the first 10 meters from the field borders. This may be related to the presence of the bird nests on the trees at the field edges and near the nesting habitats of buildings. Data also, indicated that bird damage percent differed according to the type of habitat, whereas crops nearby trees were severely damage followed by those nearby buildings and field crops. The highest damage in the wheat and sorghum fields was nearby trees and buildings that may be related to the individuals of birds stay more beside and inside nests on trees and buildings to feed and her Youngs. While the lowest bird damage was in fields nearby field crops because crops together and the damage spread over wide areas.

\section{REFERENCES}

Abbasy, M.R.A., Mostafa, M.A., Khattab, M.M.D., ElDanasory, M.A.M., Attia M.A.I., 2011. A survey and seasonal fluctuation of wild birds in different locations at Ismailia Governorate. Al-Azhar J. Agric. Res. 11, 97-108.

Bruggers, R.L., Rulle, P., 1981. Economic impact of pest birds on repining cereal in Senegal. Prot. Ecol., 3, 7-16.

De-Haven, R.W., 1974. Bird damage appraisal methods in some agriculture crops. Proc. Sixth Vert. pest. Cont. 246-248.

Hassan, A.A.G., 2018. Ecological and biological studies on some wild bird species at Sohag Governorate. M.Sc. Thesis Fac. Agric., Al-Azhar Univ., pp.152.

Metwally, A.M., Ahmed, M.A., Mahmoud, N.A., Abdel-Aal, M.M., 2009. Field trials to evaluate damage caused by wild birds to certain field crops under different habitats at Assiut Governorate. J. Agric. Sci. Mansoura Univ. 34 (2), 941-950.

Mosallm, M.A.S., 2017. Ecological and toxicological studies on some wild bird species at Assiut Governorate. M.Sc. Thesis Fac. Agric., Al-Azhar Univ., p. 110.

Omar, M.M.A., El-Danasory, M.A.M., 2014. Estimation of injury caused by house sparrow Passer domsticus niloticus (L.) in wheat crop at Assiut Governorate. J. Plant Prot. Path., Mansura Univ. 5 (10), 939-945.

Poche, R.M., Main, M.U., Hoqie, M.E., Sultana, P., 1982. Rodent damage and burrowing characteristics in Bangladesh wheat fields. J. Will. Manage. 46, 139147.

Redinger, R.F., Libay, S.L., 1979. Perches courted with glue reduce bird damage in rice field plots. Proceeding Eighth bird control, seminar, Bowling green, Ohio, Nov. 201-206.

Sibley, C.C., Monoroe, L.B., 1990 Distribution and taxonomy of birds of the world. New Haven Yale University press. 34-38.

Tharwat, M.E., 1997. Birds known to occur in Egypt. Publication of National biodiversity, Unit. No. 8, 1997, EEAA, El-Walid Press, Cairo, Egypt.

Thomson, A.L., 1964. A New Dictionary of Birds. McGrawHill Book Company, New York. 
Table 1. Survey and population dynamics of harmful bird species.

\begin{tabular}{|c|c|c|c|c|c|}
\hline \multirow[b]{2}{*}{ Common name } & \multirow{2}{*}{$\begin{array}{l}\text { Resident birds } \\
\text { Scientific name }\end{array}$} & \multicolumn{4}{|c|}{ Seasons of year study } \\
\hline & & & $\begin{array}{l}0 \\
\text { के } \\
\text { के }\end{array}$ & 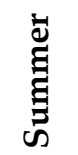 & 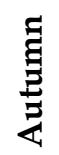 \\
\hline Crested lark & Galerida cristata & * & * & * & * \\
\hline Hooded crow & Corvus corone sardonius & ** & ** & ** & ** \\
\hline House sparrow & Passer domesticus niloticus & ** & $* * *$ & **** & ** \\
\hline Little green bee-eater & Merops orintalis clepatra & * & * & * & * \\
\hline Palm dove & Streptopelia senegalensis egyptica & ** & ** & ** & ** \\
\hline Rock dove & Columba livia schimari & $* *$ & $* *$ & $* *$ & $* *$ \\
\hline
\end{tabular}

$*=1<10 \quad * *=10<100 \quad * * *=100<500$

Table 2. Survey and population dynamics of beneficial bird species.

\begin{tabular}{|c|c|c|c|c|c|c|}
\hline \multirow[b]{2}{*}{ Common name } & \multirow{2}{*}{$\begin{array}{l}\text { Resident and migratory } \\
\text { Scientific name }\end{array}$} & \multirow[b]{2}{*}{ Time } & \multicolumn{4}{|c|}{ Season of year } \\
\hline & & & 离 & $\begin{array}{l}\text { की } \\
\text { के }\end{array}$ & 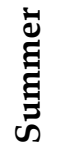 & 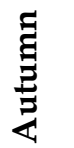 \\
\hline Black winged kite & Elanus coeruleus & Resident & * & * & * & * \\
\hline Cattle egret & Bubulcus ibis ibis & Resident & ** & $* *$ & ** & ** \\
\hline Chiffchaff & Phylloscopus collybita & Migrator & * & * & $\mathrm{X}$ & $\mathrm{X}$ \\
\hline Fantailed warbler & Cisticola juncidis & Resident & * & * & * & * \\
\hline Hoopoe & Upupa epops epopes & Resident & * & * & * & * \\
\hline Kestrl & Falco tinnunculus & Resident & * & * & * & * \\
\hline Little owi & Athene noctua glaux & Resident & * & * & * & * \\
\hline Spur winged Plover & Hoplopterus spinosus & Resident & * & * & * & * \\
\hline Swallow & Hirundo rustica savignii & Resident & * & * & * & * \\
\hline White wagtail & Motacilla alba alba & Migrator & ** & ** & $\mathrm{X}$ & $\mathrm{x}$ \\
\hline Yellow wagtail & Motacilla flava & Resident & * & * & $X$ & $X$ \\
\hline
\end{tabular}

$*=1<10 \quad * *=10<100 \quad X=$ Absent

Table 3. Classification of some wild bird species collected from newly reclaimed areas Akhmim and Tahta districts at Sohag Governorate.

\begin{tabular}{llll}
\hline Common name & Scientific name & Family & Order \\
\hline Black-winged kite & Elanus coeruleus & Acciptridae & Accipitres \\
Cattle egret & Bubulcus ibis ibis & Ardidae & Ciconiformes \\
Chiffchaff & Phylloscopus collybita & Sylviidae & Passeriformes \\
Crested lark & Galerida cristata & Alaudidae & Passeriformes \\
Fantailed warbler & Cisticola juncidis & Muscicapidae & Passeriformes \\
Hoopoe & Upupa epops epopes & Upupidae & Coracuformes \\
Hooded crow & Corous corone sardonius & Corvidae & Passeriformes \\
House sparrow & Passer domesticus niloticus & Passeridae & Passeriformes \\
Kestrl & Falco tinnunculus & Falconidae & Accipitres \\
Little owl & Athene noctua glaux & Strigidae & Strigiformes \\
Little green bee-eater & Merops orintalis cleopatra & Miropidae & Coracuformes \\
Palm dove & Streptopelia senegalensis egyptica & Columbidae & Columbiformes \\
Rock dove & Columba livia schimari & Columbidae & Columbiformes \\
Spur winged Plover & Hoplopterus spinosus & Charadrudae & Charadrufomes \\
Swallow & Hirundo rustica savignii & Hirundidae & Passeriformes \\
White wagtail & Motacilla alba alba & Motacillidae & Passeriformes \\
Yellow wagtail & Motacilla flava & Motacillidae & Passeriformes \\
\hline
\end{tabular}


Table 4. Average percentage of birds damage on wheat and sorghum crops at Akhmim district during 2015/2016.

\begin{tabular}{|c|c|c|c|c|c|c|c|c|}
\hline \multirow{3}{*}{$\begin{array}{l}\text { Distance } \\
\quad(\mathrm{m})\end{array}$} & \multirow{2}{*}{\multicolumn{3}{|c|}{$\begin{array}{c}\% \text { of birds damage on wheat } \\
\text { Location }\end{array}$}} & \multirow[b]{3}{*}{ Mean } & \multirow{2}{*}{\multicolumn{3}{|c|}{$\begin{array}{c}\% \text { of birds damage on sorghum } \\
\text { Location }\end{array}$}} & \multirow[b]{3}{*}{ Mean } \\
\hline & & & & & & & & \\
\hline & Buildings & $\begin{array}{l}\text { Field } \\
\text { crops }\end{array}$ & Trees & & Buildings & $\begin{array}{l}\text { Field } \\
\text { crops }\end{array}$ & Trees & \\
\hline 10 & 15 & 8 & 28 & $17.00 \mathrm{a}$ & 38 & 6 & 48 & $30.67 a$ \\
\hline 20 & 10 & 5 & 23 & 12.67ab & 24 & 4 & 30 & 19.33ab \\
\hline 30 & 6 & 2 & 12 & 6.67ab & 12 & 3 & 18 & $11.00 \mathrm{ab}$ \\
\hline 40 & 1 & 0 & 6 & $2.33 b$ & 8 & 1 & 10 & $6.33 b$ \\
\hline 50 & 1 & 0 & 2 & $1.00 \mathrm{~b}$ & 4 & 0 & 4 & $2.67 \mathrm{~b}$ \\
\hline Mean & $6.60 \mathrm{ab}$ & $3.00 \mathrm{~b}$ & $14.20 \mathrm{a}$ & 7.93 & $17.20 \mathrm{ab}$ & $2.80 \mathrm{~b}$ & $22.00 \mathrm{a}$ & 14.00 \\
\hline
\end{tabular}

* Means with each examined weeks for treatments followed by the same letter are not significant differences at the 0.05 level probability.

Table 5. Average percentage of birds damage on wheat and sorghum crops at Tahta district during 2015/ 2016.

\begin{tabular}{|c|c|c|c|c|c|c|c|c|}
\hline \multirow{3}{*}{$\begin{array}{l}\text { Distance } \\
\text { (m) }\end{array}$} & \multicolumn{3}{|c|}{$\%$ of birds damage on wheat } & \multirow{3}{*}{ Mean } & \multicolumn{3}{|c|}{$\%$ of birds damage on sorghum } & \multirow{3}{*}{ Mean } \\
\hline & \multicolumn{3}{|c|}{ Location } & & & Location & & \\
\hline & Buildings & Field crops & Trees & & Buildings & Field crops & Trees & \\
\hline 10 & 12 & 5 & 21 & $12.67 \mathrm{a}$ & 34 & 12 & 44 & $30.00 \mathrm{a}$ \\
\hline 20 & 8 & 2 & 14 & $8.00 \mathrm{ab}$ & 24 & 6 & 30 & $20.00 \mathrm{ab}$ \\
\hline 30 & 6 & 1 & 7 & $4.67 \mathrm{ab}$ & 14 & 6 & 14 & $11.33 \mathrm{~b}$ \\
\hline 40 & 1 & 0 & 2 & $1.00 \mathrm{~b}$ & 6 & 2 & 4 & $4.00 \mathrm{~b}$ \\
\hline 50 & 0 & 0 & 0 & $0.00 \mathrm{~b}$ & 2 & 0 & 4 & $2.00 \mathrm{~b}$ \\
\hline Mean & $5.40 \mathrm{a}$ & $1.60 \mathrm{a}$ & $8.80 \mathrm{a}$ & 5.27 & $16.00 \mathrm{a}$ & $5.20 \mathrm{~b}$ & $19.20 \mathrm{a}$ & 13.47 \\
\hline
\end{tabular}

* Means with each examined weeks for treatments followed by the same letter are not significant differences at the 0.05 level probability. 


\section{دراسات على بعض أنواع الطيور الضارة والثافعة في الأراضي المستصلحة حديثاً في محافظة سوهاج}

$$
\begin{aligned}
& \text { محمود مبارك عبدالعال عمر } \\
& \text { قسم الحيوان الزراعي والنياتودا، كلية الزراعة، جامعة الأزهر فرع أسيوط، أسيوط، مصر مير مارك } \\
& \text { البريد الإليكتروني: Mahmoud.omar75@azhar.edu.eg }
\end{aligned}
$$

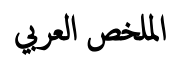

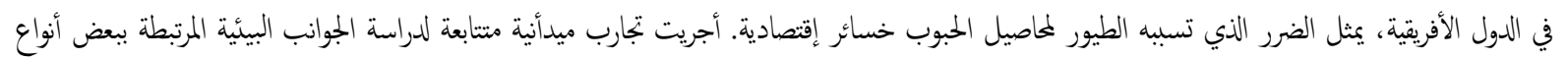

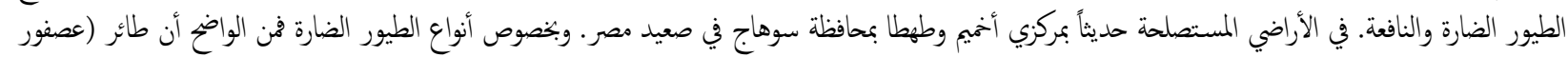

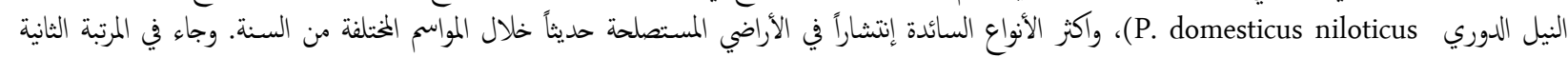

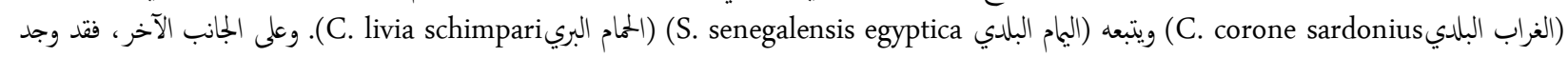

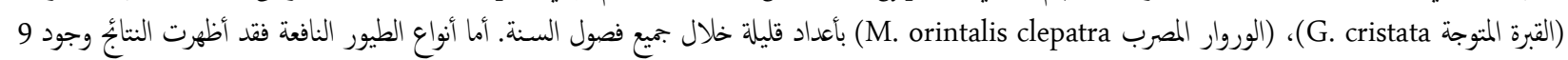

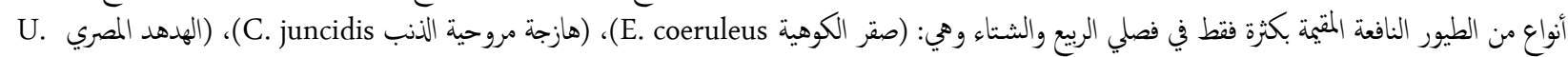

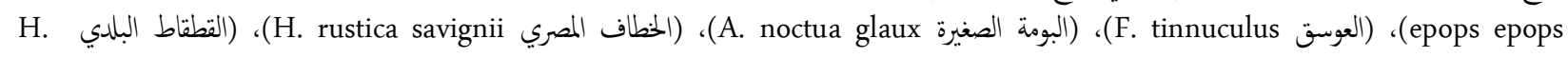

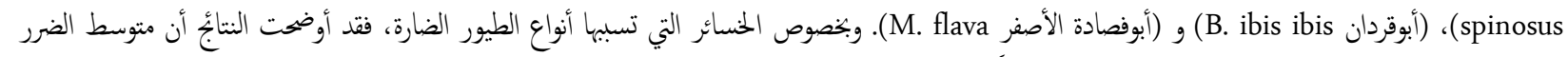

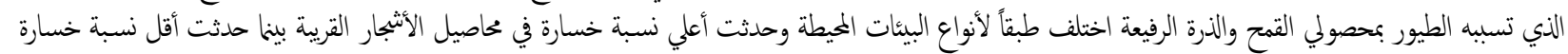

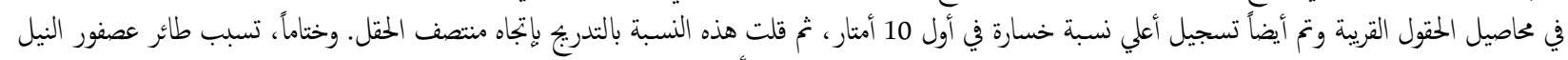

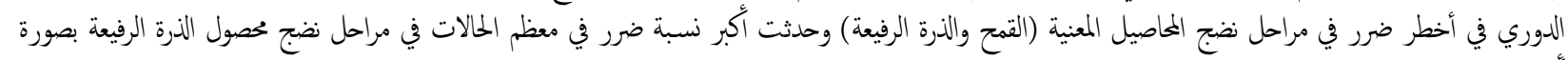
أكبر من محصول القمح.

$$
\text { الكلمات المفتاحية: مسح الأراضي، تعداد السكان، مناطق مستصلحة حديثًا، الطيور الضارة، القمح، الذزة الرفيعة. }
$$

